\title{
Quantum Superposition/Social Superposition and Classic Sociological Theory
}

\author{
Steven Gerardi \\ Professor Emeritus of Sociology, New York City College of Technology, CUNY, New York, USA \\ Email: Tutti50Wag@aol.com
}

How to cite this paper: Gerardi, S. (2018). Quantum Superposition/Social Superposition and Classic Sociological Theory. Sociology Mind, 8, 21-24.

https://doi.org/10.4236/sm.2018.81002

Received: November 18, 2017

Accepted: January 6, 2018

Published: January 9, 2018

Copyright $\odot 2018$ by author and Scientific Research Publishing Inc. This work is licensed under the Creative Commons Attribution International License (CC BY 4.0).

http://creativecommons.org/licenses/by/4.0/

\begin{abstract}
This effort suggests that the Quantum physics concept of Superposition (Superposition suggests that any two states can be combined as one, becoming one distinct state) has had a profound effect on early sociological classic theory. Therefore, in response to the increased application of Quantum Superposition in the development of classical sociological theory, this effort has referred to this adaptation as "Social Superposition". Defined "Social Superposition" is a Sociological Theory having two social states combined and layered as one. However, when one social state is observed, a new and unique social state emerges, social change has occurred.
\end{abstract}

\section{Keywords}

Classical Sociological Theories, Quantum Superposition Social Superposition

\section{Context of the Research}

During the turn of the $20^{\text {th }}$ century many of the intelligentsia were familiar with the scientific, and artistic advances of the time. Indeed, this is significant due to the Sociology of Knowledge's placing importance on the nexus between human ideas and their effect on society, technology and science (Gerardi, 2017). In an original work entitled "The Dielectric Relationship between Religion and the Ideology of Science", this paper suggested that the secularization of many of the world religions has created a human identity which seeks to understand the world through a systemic orderly stance. This orderly stance was a major factor in the culmination of the ideology of science (Gerardi, 2012).

As was mentioned earlier the $20^{\text {th }}$ Century witnessed accelerated advancements, especially in science. One such $20^{\text {th }}$ century period man was Einstein, and his work on Theory of Relativity. Central to the Theory of Relativity is the con- 
cept of Superposition. Superposition suggests that any two states can be combined as one. Indeed, becoming one distinct state. Einstein's example of this concept was a keg of gunpowder. As a superposition it is both explosive and nonexplosive, all in one state simultaneously. Furthermore, a superposition becomes either one or the other, when an observation takes place ("Copenhagen Interpretation"). The concept of Superposition has had a profound effect on the early sociologist's work and their theories. This effort will argue that Superposition influence: a) Durkheim's work on the two forms of Collective Conscience; b) Weber's work on the Principle of Rationality/Disenchantment; c) Simmel's concept of the Stranger; d) Marx's work on “Historical Materialism”, and e) G.H. Meads concept of Self. As was mentioned earlier because Quantum Superposition has had a major influence on Classical Sociological Theory, this effort will suggest that the outcomes of these earlier theories can be referred to as "Social Superposition" (Theory having two social states combined and layered as one. However, when one social state is observed, a new and unique social state emerges creating social change). This effort will first discuss the effects of Social Superposition on Durkheim, second Weber, third Simmel, fourth Marx and lastly GH Mead.

\section{Social Superposition's Influence on Classical Sociological Theory}

\subsection{Durkheim and the Collective Conscience}

Durkheim Identified two forms of solidarity, Mechanical and Organic. Durkheim's main concept is that the current collective conscience within society is not eradicated completely; rather a new moral ideal emerges (Organic), validating the specialized division of labor and the movement toward individuality (Gerardi, 2010) Here the concept of "Social Superposition" can be seen in the two forms of Solidarities simultaneously as one (Social Superposition). But when Organic is observed, it transforms into a new and unique state, creating social change.

\subsection{Weber and the Principle of Rationality}

Weber's concept of Principle of Rationality/Disenchantment is the degree to which the magical elements of thought in society are displaced by that of the rational, intellectual and objective articulation of the world. The mysteries of nature and the "mystic experience" to a substantial extent progress to an intellectual, impersonal, calculating image based in rules and scientific laws. Hence, this attitude seeks the "meaning of inner-worldly occurrences" through empirical and scientific thought. Thus, pushing back the supernatural into the realm of the irrational. Empirical knowledge and technological know-how led to the control of the natural world through calculation, and intellectual elaboration (Gerardi, 2010). 
Weber's concept of the Principle of Rationality/Disenchantment has two world images (Social Superposition) associated with the principle (irrational and rational). However, when the rational image is observed, a new and unique state emerges (intellectual elaboration) (i.e. Modern Medical standards vs. Witch Doctor magic) based in Science and technology leading to social change.

\subsection{Simmel and the Stranger}

Simmel argued that in all human relationships there is a unity of nearness and remoteness, indifference and involvement (Social Superposition). Hence, human relationships are both near and far at the same time. This nearness and farness produces tensions only when social difference is seen (i.e. race, religion, city vs. country dweller, etc.). When these differences are observed the "Stranger" emerges. Simmel supports this point by identifying the social position of being Jewish in Europe (seen as a minority population). Hence, the Stranger receives differential treatment under the tax system (Beede Tax) (based upon religious doctrine). A Jewish person under the Beede tax had to pay a fixed tax per single person. On the other hand, for the Christian the tax was based on changing fortune. Thus, this taxation policy discriminated based on the "religious strangeness" in Europe (Gerardi, 2010).

Once again, we see this concept of two states combined into one Social Superposition (near and far) until the different background (of being Jewish) is identified as a new and unique state of the "Stranger".

\subsection{Marx and Historical Materialism}

Marx viewed modern capitalist society as an historical process of alienation, preventing humanity from realizing their true "Species Being" (free creative force). Marx believed that human history is the collective creative activity of humanity, the existence of living individuals, their physical organization, and their relationship to nature (Species Being). Moreover, Marx's philosophy of "Historical Materialism" incorporates the idea that history is not merely an accumulation of accidents or deeds of great men, rather the development of humanity through creative labor and productive forces. Humanity transforms, develops and changes the world, and hence is the past, present and future (species-being). Whereas, the species-nature of animals is rooted in the internal repetition of activities, accepting what nature offers.

However, modern capitalism perverts the human "species-being" into a means of existence, rather than a free conscious creative activity, referred to as alienated labor. Under alienated labor humanity feels free only to act in its most animal functions, hence being alienated from self (creative). This existence decreases humanities advantage over animals, reduced humanity to maintaining only his/her physical needs (like an animal in the wild and not its free creative needs) (Gerardi, 2010).

Here Marx sees humanity's as being both creative and non-creative in one 
state (Social Superposition). However, modern capitalism transforms humanities creativity (species-being) into Alienated labor. Alienated labor suggests that the product of human labor is not a free and creative outcome, rather the product stands against and above the creative state of humanity (the product is more important than the sum of its' parts-leading to a devaluation of Human life-objectification). Once Alienated labor is recognized it becomes a new and unique human state, creativity is lost, along with humanities advantage over animals. Social change has occurred.

\subsection{G.H. Mead and Symbolic Interaction}

G.H. Mead identified two distinctive qualities of self-development, the social entity, and the individual perception of self. According to Mead for self to emerge there must be a means by which the individual takes on an objective, impersonal attitude toward him/herself. Language is the impersonal position because the individual hears internally his/her own significant symbols in an objective manner, processing to an objective view of his/her own thoughts and utterances (Gerardi, 2010).

Mead identifies two concepts of self-development, the "I" and the "Me" (Social Superposition). The "I," according to Mead is the unique sense of self, and the "ME" is the social concept of self. Once a person enters the "looking Glass Self" (Cooley, the behavior of others is a mirror reflection of self) he/she is now seen as new and unique self. A new and socialized individual emerges (Social Superposition).

\section{Conclusion}

This effort suggested that the early sociologists were profoundly affected by the concept of Quantum Superposition. Therefore, this effort has referred to this epistemology as "Social Superposition". "Social Superposition" is the changing social movement of space, time, located in the human mind; imbedded in the collective memories of each successive generation, in which social change is viewed a unique historical/cultural event. The theories of the early Sociologists as this effort has suggested can be seen developed employing the concept of Quantum Superposition, or "Social Superposition" ending in social change. Finally, in the interest of science, Social Superposition should be applied to Contemporary Sociological Theory.

\section{References}

Gerardi, S. (2010). A Brief Survey of the Sociological Imagination (3rd ed.). Dubuque, IA: Kendall/Hunt.

Gerardi, S. (2012). The Dialectical Relationship between Religion and the Ideology of Science. Sociology Mind, 12, 50-52. https://doi.org/10.4236/sm.2012.21006

Gerardi, S. (2017). The Use of Computer/Apps and the Negative effects on Children's Intellectual Outcomes. Sociology Mind, 7, 128-132.

https://doi.org/10.4236/sm.2017.73009 